\title{
Carbon storage and soil organic matter stabilisation in near-natural, restored and embanked Swiss floodplains ${ }^{\text {is }}$
}

\author{
G. Bullinger-Weber ${ }^{\mathrm{a}, *}$, R.-C. Le Bayon ${ }^{\mathrm{b}}$, A. Thébault ${ }^{\mathrm{c}}$, R. Schlaepfer $^{\mathrm{d}}$, C. Guenat $^{\mathrm{d}}$ \\ a Biogeosciences Laboratory, Institute of Geology and Palaeontology, University of Lausanne, UNIL-Dorigny, 1015 Lausanne, Switzerland \\ b Soil E' Vegetation Laboratory, Institute of Biology, University of Neuchâtel, Emile-Argand 11, 2000 Neuchâtel, Switzerland \\ c Mathématiques, Informatique et Statistique pour l'Environnement et l'Agronomie (MISTEA), INRA SUPAGRO, UMR 729, 2 Place Viala, 34060 Montpellier Cedex, France

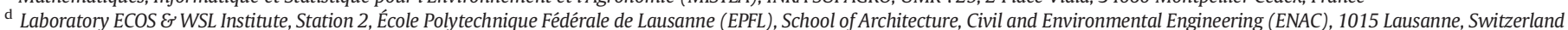

\section{A R T I C L E I N F O}

\section{Article history:}

Received 3 December 2012

Received in revised form 24 December 2013

Accepted 31 December 2013

Available online 4 February 2014

\section{Keywords:}

Floodplains

Alluvial soils

River restoration

Carbon storage

Soil organic matter stabilisation

\begin{abstract}
A B S T R A C T
Over recent decades, the number of floodplain restoration projects has increased worldwide. In Switzerland, several projects have been implemented to maintain or recreate ecological functions of floodplains. Despite this, little is known about the potential of floodplain soils to release and/or accumulate carbon. In alluvial soils, carbon storage is strongly influenced by fluvial dynamics, and therefore a better understanding of carbon fluxes and stocks in such settings is clearly needed.

To evaluate the impact of river restoration on carbon storage in alluvial soils, we aimed to quantify and explain carbon storage and soil organic matter (SOM) stabilisation in the uppermost soil humic layer. Three floodplains were investigated showing each of them different levels of human disturbance: a near-natural section along the Rhine River, and both restored and embanked sections along the Thur River and Emme River. Carbon storage was determined by total organic carbon (TOC) stocks. SOM stabilisation was evaluated by considering the TOC content in different granulometric fractions (1000-2000 $\mu \mathrm{m}, 500-1000 \mu \mathrm{m}$, and 250-500 $\mu \mathrm{m})$ and the macroaggregate formation, i.e. the abundance of water-stable aggregates (WSA) and the mean weight diameter of macro-aggregates (MWD).

Our results show that the carbon storage and SOM stabilisation parameters were all related to soil properties such as clay, silt and total iron contents of the upper humic layer. Within each floodplain, carbon storage and SOM stabilisation parameters differed according to soil profile groups, thus reflecting a soil gradient evolution from bare alluvium soils to more stabilised soils and a hydric functioning (soils with hydromorphic features). In addition, river restoration showed various impacts on carbon storage and SOM stabilisation parameters depending on the floodplains, with a significant difference between embanked and restored sections for the Emme floodplain and no difference for the Thur floodplain.
\end{abstract}

(c) 2014 Elsevier B.V. All rights reserved.

\section{Introduction}

Wetlands play an important role in the global carbon cycle (Mitra et al., 2005), but their carbon source and sink functions are complex. While most studies on carbon budget have focused on peatlands, nonpeat wetlands, such as near-natural riverine floodplains and restored riverine floodplains, have scarcely been considered (Cierjacks et al., 2011). Compared to other wetland soils, alluvial soils are much more variable in space and time, resulting from a succession of sedimentation/erosion processes combined with an in situ soil formation between flood events

\footnotetext{
This is an open-access article distributed under the terms of the Creative Commons Attribution-NonCommercial-No Derivative Works License, which permits noncommercial use, distribution, and reproduction in any medium, provided the original author and source are credited.

* Corresponding author at: Institute of Construction and Environmental Technology, University of Applied Sciences of Western Switzerland, Boulevard de Pérolles 80, P.O. Box 32, CH-1705 Fribourg, Switzerland. Tel.: + 41264296336.

E-mail address: geraldine.bullinger@gmail.com (G. Bullinger-Weber).
}

(Gerrard, 1987), thus leading to a gradient of soil evolution from bare soils to well-developed soils under forests.

Focusing on humic layers, i.e. soil layers containing high proportions of soil organic matter (SOM), sedimentation/erosion events lead to i) the inheritance of organic matter brought by sedimentation (Bechtold and Naiman, 2009), and/or ii) the erosion of humic layers (Hoffmann et al., 2009), and/or iii) the burying of humic layers under new sediments (Blazejewski et al., 2009; Cierjacks et al., 2010). SOM accumulation also depends on in situ soil pedogenesis between floods, as well as the elevation from the riverbed, especially along a primary forest succession from pioneer tree species to old-growth uneven-aged forest (Van Cleve et al., 1993). Similarly, Zehetner et al. (2009) showed that SOM accumulation depends on soil age, with the highest rates to be found within 50 to 100 years of soil formation. Focusing more specifically on soil organic carbon, the major component of soil organic matter, its storage in alluvial soils may vary as a function of several variables. For instance, the frequency of flooding (Bernal and Mitsch, 2008) and the concomitant deposition of carbon-rich sediments usually lead to an increase in soil organic 
carbon stocks (Cierjacks et al., 2011; Wohl et al., 2012), either in the humic layer or in the underlying organic matter layers enriched within the profile (Blazejewski et al., 2009; Cierjacks et al., 2010) thus preserving autochthonous organic material (Zehetner et al., 2009). Moreover, vegetation directly influences soil carbon accumulation and consequently soil development by aboveground and belowground inputs (Giese et al., 2000 ) leading to high spatial heterogeneity in terms of vertical and horizontal SOM distribution (Blazejewski et al., 2009; Drouin et al., 2011). Soil properties, such as profile development, texture, moisture and water table also greatly affect carbon storage (Mitra et al., 2005; Steiger et al., 2001). Carbon content is hence significantly and positively correlated with the clay content in alluvial deposits (Bai et al., 2005; Cabezas and Comin, 2010). For a given hydrological regime, a causal relationship may exist between organic carbon concentrations and average soil moisture (Barton et al., 2000). Organic carbon dynamics in alluvial soils may also be modified by human disturbance mainly due to changes of natural flood dynamics (river diversion, dam; Tockner and Stanford, 2002) and/ or changes in vegetation composition (tree cutting, plantation, exotic plant invasion; Gerber et al., 2007). River restoration also causes soil disturbances such as the removal of organic-rich topsoil or the use of heavy machinery (Bruland and Richardson, 2005; Unghire et al., 2011).

Another aspect of SOM poorly understood is its stabilisation in soils which consists of several mechanisms, namely 1 ) physical protection, 2) physicochemical stabilisation, by binding SOM and mineral particles (i.e. clay and silt) leading to occlusion of organic matter into microand macro-aggregates, and 3) biochemical stabilisation (Six et al., 2002). Largely studied in agricultural soils, the formation of macroaggregates (larger than $250 \mu \mathrm{m}$ ) is usually considered as the aggregation product of micro-aggregates $(>53-250 \mu \mathrm{m})$, silt-clay sized aggregates and particular organic matter. Depending on aggregate size, von Lützow et al. (2007) suggested that the time-scale of SOM stabilisation varies from 1-10 years for macro-aggregates larger than $250 \mu \mathrm{m}$ to 10 100 years for micro-aggregates $(20-250 \mu \mathrm{m})$. Focusing on alluvial soils, SOM stabilisation has been usually evaluated by the distribution of organic carbon content in particle-size fractions, the latter being assumed to have a different role in SOM turnover and then in assessing the state of floodplain restoration (Wigginton et al., 2000). These authors ensured that it may be sufficient to analyse SOM content in conjunction with aggregate size distributions to monitor the long-term trajectory of restoration efforts. In addition, the macro-aggregate characteristics, i.e. the water stable aggregate abundance (WSA) and the mean weight diameter of macro-aggregates (MWD) are also widely used to evaluate SOM stabilisation in alluvial soils (Bullinger-Weber et al., 2007; Guenat et al., 1999; Onweremadu et al., 2010).

In a context of floodplain restoration, little is still known about the impact of river restoration on soil properties, and especially on carbon storage and SOM stabilisation despite a considerable increase in the number of floodplain restoration projects during the last decade (Palmer and Bernhardt, 2006; Palmer et al., 2005). Only some research has highlighted the necessity to include carbon storage in the framework of river restoration (Ballantine and Schneider, 2009; Cabezas and Comin, 2010; Cierjacks et al., 2010).

As a consequence, the aim of our research was to quantify and explain carbon storage and soil organic matter stabilisation in the uppermost humic layer in terms of soil properties, soil profile groups (related to soil morphology), and three levels of human influence (near-natural, restored and embanked). Three floodplains were investigated: the Rhine floodplain is considered as a near-natural one, while the Thur and the Emme floodplains are both composed of one restored section and one embanked one. We hypothesized that: 1 . Carbon stocks and SOM stabilisation parameters are related to soil properties, especially soil texture; 2 . Carbon stocks and SOM stabilisation parameters differ among profile groups (defined by morphological criteria) within each floodplain; 3. Carbon stocks and SOM stabilisation parameters vary between embanked and restored sections within the Emme and Thur floodplains.

\section{Material and methods}

\subsection{Floodplain descriptions}

We investigated three Swiss floodplain areas differing in the levels of human disturbance. Their main characteristics are given in Table 1. The Rhine floodplain (Canton of Graubünden - GR) located along the Rhine River is a site of Swiss national importance and is considered as a nearnatural floodplain due to its vegetation composition (Gallandat et al., 1993) and the absence of embankments in the surroundings.

The floodplain along the Emme River (canton of Bern - BE) is the first restoration project by river widening conducted in Switzerland. This floodplain had been embanked until 1991, after which a section was widened in 1991/92 and 1998/99. The restoration consisted of the mechanical removal of the embankments along a $530 \mathrm{~m}$ long section and the river was widened by $30 \mathrm{~m}$. Two sections were studied, a restored section and an adjacent embanked section.

The floodplain along the Thur River (canton of Thurgau - TG) is currently the biggest widening river restoration project in Switzerland. Restoration of the site was conducted in two steps: first, following a major flood in 1995, the embankments were partly destroyed thus allowing river bank erosion. Secondly, in 2002, the river bed was widened by the mechanical removal of the embankments along a $1.5 \mathrm{~km}$ section from 50 to $110 \mathrm{~m}$ in width, and the banks were stabilised by plantations of willow (Salix viminalis; Pasquale et al., 2011). For both the Emme and the Thur floodplains, we chose two sections, one restored and one embanked, this latter being located upstream in order to have the state of the floodplain prior to river widening.

\subsection{Preliminary soil survey}

A preliminary soil survey was performed using an auger boring in order to evaluate the variability of soil morphologies in the floodplains (Fournier et al., 2013). Along transects perpendicular to the river flow, a total of 104, 260 and 125 borings were performed in the Rhine floodplain ( 3 transects), the Emme floodplain (10 transects) and the Thur floodplain (6 transects). The following morphological descriptors were taken into account to describe each boring: total soil depth from top surface to gravel limit, number of layers, number of humic layers, corresponding to soil layers containing high proportions of soil organic carbon (related to a brown colour), and number of textural layers (i.e. layers that differ according to their particle-size distribution) found in the profile. Additionally, the main texture of soil layers as well as presence of hydromorphic features, coarse elements (particle size $>2 \mathrm{~mm}$ ) and roots in the uppermost humic layer were noticed. Then, based on these morphological descriptors, clustering analyses (by Ward's method) were performed in order to get a hierarchical classification of soil morphologies for each floodplain. Resulting from these hierarchical classifications, different soil clusters were then obtained in each floodplain, six for the Rhine floodplain (GR 1 to GR 6), eight for the Emme floodplain (BE 1 to BE 8) and six for the Thur floodplain (TG 1 to TG 6). Details of these different soil clusters are given in Appendix A.

\subsection{Soil profile sampling}

A soil profile sampling campaign (final study) was performed in spring 2010. At each floodplain, we described and sampled three representative soil profiles (from 0 to $30 \mathrm{~cm}$ ) for each soil cluster resulting from hierarchical classification. These three soil profiles of each cluster are named "soil profile groups". In the field, the thickness of the uppermost humic layer (in $\mathrm{cm}$ ) was measured. On the whole soil profile, total depth from top surface to pebble limit (Total Depth in $\mathrm{cm}$ ) was measured and the presence or absence of hydromorphic features was indicated (Hydro, composed by 3 classes: $0=$ no hydromorphic features, $1=$ redoxic marks, 2 = reductic marks). Moreover, an alluvial index (Alluvial Index) reflecting alluvial dynamics (Bullinger-Weber and 
Table 1

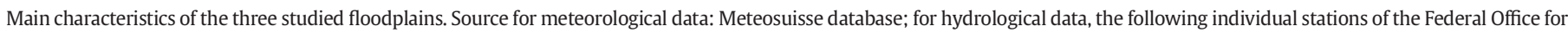

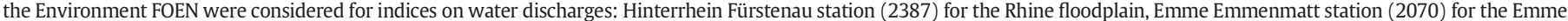

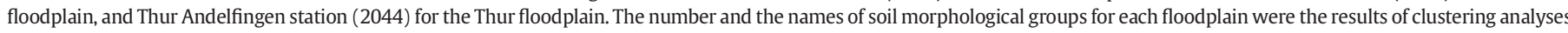

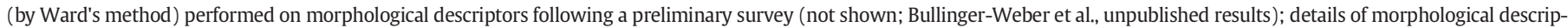
tions of soil groups in Appendix A.

\begin{tabular}{|c|c|c|c|c|c|}
\hline \multirow[b]{3}{*}{ Canton (local name) } & \multicolumn{5}{|l|}{ Floodplains } \\
\hline & \multirow{2}{*}{$\begin{array}{l}\text { Rhine (GR) } \\
\text { Graubünden (Rhäzuns) }\end{array}$} & \multicolumn{2}{|l|}{ Emme (BE) } & \multicolumn{2}{|l|}{ Thur (TG) } \\
\hline & & \multicolumn{2}{|l|}{ Bern (Birnen) } & \multicolumn{2}{|c|}{ Thurgau (Schäffäuli) } \\
\hline Altitude a.s.l. (m) & 600 & \multicolumn{2}{|l|}{500} & \multicolumn{2}{|l|}{365} \\
\hline Annual precipitation (mm) & 870 & \multicolumn{2}{|l|}{1050} & \multicolumn{2}{|l|}{1000} \\
\hline Mean annual temperature $\left({ }^{\circ} \mathrm{C}\right)$ & 10.1 & \multicolumn{2}{|l|}{9.4} & \multicolumn{2}{|l|}{7.9} \\
\hline Mean annual discharge $\left(\mathrm{m}^{3} / \mathrm{s}\right)$ & 40 & \multicolumn{2}{|l|}{19} & \multicolumn{2}{|l|}{47} \\
\hline Minimum annual discharge $\left(\mathrm{m}^{3} / \mathrm{s}\right)$ & 23 & \multicolumn{2}{|l|}{9} & \multicolumn{2}{|l|}{23} \\
\hline Maximum annual discharge $\left(\mathrm{m}^{3} / \mathrm{s}\right)$ & 60 & \multicolumn{2}{|l|}{28} & \multicolumn{2}{|l|}{76} \\
\hline HQ2-HQ50-HQ100 discharges $\left(\mathrm{m}^{3} / \mathrm{s}\right)$ & $354-761-830$ & \multicolumn{2}{|l|}{$267-545-593$} & \multicolumn{2}{|l|}{ 572-999-1067 } \\
\hline Alluvial deposit's composition & Calcareous pebbles and sand & \multicolumn{2}{|c|}{ Calcareous pebbles and sand } & \multicolumn{2}{|c|}{ Calcareous pebbles and sand } \\
\hline Human disturbance & Very low & Restored & Embanked & Restored & Embanked \\
\hline Number and names of soil morphological groups & 6/ GR 1 to GR 6 & $7 / \mathrm{BE} 1$ to $\mathrm{BE} 7$ & $1 / \mathrm{BE} 8$ & $5 / \mathrm{TG} 1$ to TG 5 & $1 /$ TG 6 \\
\hline
\end{tabular}

Gobat, 2006) was calculated by dividing the total number of horizons by the total depth of the soil profile. This alluvial index reflects thus the number of successive alluvium deposits for the total depth of the profile.

Soil sampling for physicochemical analyses was performed only on the uppermost humic layer even if it was covered by recent alluvial deposits, and thus not found at the surface of the profile. The absence (bare soils) or presence of a single humic layer was observed in all soil profiles (60 soil profiles), as well as in most of the auger borings performed during the preliminary soil survey ( $97.8 \%$ auger borings).

\subsection{Physicochemical analyses}

Total carbon (TC) and mineral carbon (IC) concentrations were measured by a $680{ }^{\circ} \mathrm{C}$ combustion catalytic oxidation method using a TOC-Shimadzu analyser and total organic carbon (TOC) concentration $(\mathrm{g} / 100 \mathrm{~g})$ was calculated by deducting the IC concentration from the TC concentration. Bulk density $\left(\mathrm{t} \mathrm{m}^{-3}\right)$ was also measured in order to calculate TOC stock (in $\mathrm{t} \mathrm{ha}^{-1}$ ) by multiplying it with TOC concentration and the thickness of the uppermost humic layer.

Granulometric fractionation by wet-sieving (adapted from Kemper and Rosenau, 1986) allowed isolation of four granulometric fractions (2000-5000 $\mu \mathrm{m}, 1000-2000 \mu \mathrm{m}, 500-1000 \mu \mathrm{m}$ and 250-500 $\mu \mathrm{m})$. An amount of $30 \mathrm{~g}$ of dry soil sieved at $5 \mathrm{~mm}$ was weighed and rewetted to $\mathrm{pF}=0$. Wet-sieving using a series of stacked sieves $(2 \mathrm{~mm}, 1 \mathrm{~mm}$, $0.5 \mathrm{~mm}$ and $0.250 \mathrm{~mm}$ ) was then performed for $10 \mathrm{~min}$. The four granulometric fractions obtained were dried at $45^{\circ} \mathrm{C}$ to preserve organic matter, and then weighed. TOC content $(\mathrm{g} / 100 \mathrm{~g})$ was then quantified as previously described for three granulometric fractions: 1000 $2000 \mu \mathrm{m}$ (TOC1000), 500-1000 $\mu \mathrm{m}$ (TOC500) and 250-500 $\mu \mathrm{m}$ (TOC250). As the fraction 2000-5000 $\mu \mathrm{m}$ comprised exclusively gravels, no data of TOC concentration was available. Aggregation formation was quantified as abundance of water stable aggregates (WSA \%) and mean weight diameter of macro-aggregates (MWD mm) were measured using also the wet-sieving method (Kemper and Rosenau, 1986). The four fractions were dried at $105{ }^{\circ} \mathrm{C}$ and weighed. Finally, sand content for each aggregate fraction was determined by dispersion with hexametaphosphate $\left(5 \mathrm{~g} \mathrm{l}^{-1}\right)$. WSA and MWD were calculated according to the Eqs. (1) and (2) respectively:

$\mathrm{WSA}(\%)=\left[\left(\mathrm{W}_{2 \mathrm{~mm}}+\mathrm{W}_{1 \mathrm{~mm}}+\mathrm{W}_{0.5 \mathrm{~mm}}+\mathrm{W}_{0.25 \mathrm{~mm}}\right) / \mathrm{W}_{\text {tot }}\right] * 100$

$\operatorname{MWD}(\mathrm{mm})=\left(\left(3.5 \mathrm{~mm} * \mathrm{WSA}_{2 \mathrm{~mm}}\right)+\left(1.5 \mathrm{~mm} * \mathrm{WSA}_{1 \mathrm{~mm}}\right)\right.$ $+\left(0.75 \mathrm{~mm} * \mathrm{WSA}_{0.5 \mathrm{~mm}}\right)$

$\left.+\left(0.375 \mathrm{~mm} * \mathrm{WSA}_{0.25 \mathrm{~mm}}\right)\right) / 100$
$\mathrm{W}_{\text {tot }}=$ initial weight of soil sample with deduction of mineral particles $>2 \mathrm{~mm}$; and WSA "I"mm $=$ the proportion of the total waterstable aggregates in the corresponding size fraction after deducting the weight of sand/gravel particles (upon dispersion and passing through the same sieve).

After a preliminary destruction of organic matter by $\mathrm{H}_{2} \mathrm{O}_{2}(10 \%)$, the particle size distribution of the uppermost humic layer (modified Robinson pipette method according to Carter and Gregorich, 2007) was determined as the clay content (\%), the silt content (\%) and the sand content (\%). Calcium carbonates $\left(\mathrm{CaCO}_{3} \%\right)$ of the uppermost humic layer were measured using the Calcimeter Bernard (Lamas et al., 2005). Finally, total iron content (in g/100 g) was quantified by $\mathrm{X}$-ray fluorescence spectrometry on pressed powder pellets (XRF, Philips PW 2400).

\subsection{Statistical analysis}

Statistical analyses were performed with R.2.14.0 (R development Core Team, 2011) and Statistica 11. The carbon storage was described by the organic carbon stocks (TOC stock) and the SOM stabilisation by the following parameters: carbon content in the granulometric fractions (TOC1000, TOC500 and TOC250), abundance of water-stable macroaggregates (WSA) and mean weight diameter of macro-aggregates (MWD). The above-mentioned variables concerning the different river systems namely, site (floodplain), levels of human disturbance (restored, embanked) and soil clusters within each floodplain were considered. The following soil properties were taken into account to explain carbon stocks and SOM stabilisation parameters: clay, silt and sand contents as well as $\mathrm{CaCO}_{3}$ and total iron contents. Moreover, soil properties about the entire soil profile were also taken into consideration: total soil depth, presence or absence of hydromorphic features and alluvial index.

A Multivariate Analysis of Dependency based on the generalized linear model (GLM) that takes into account both continuous and categorical predictor variables was applied. As a first step, the overall dependency between carbon storage and SOM stabilisation parameters (response variables) on one side and the soil properties (predictors) on the other side was tested. As a second step, the dependency between each response variable and predictors was tested.

Within each floodplain, differences in the carbon storage parameters between soil profile groups were tested by analysis of variance (oneway ANOVA) followed by Tukey Post-hoc tests to highlight significant differences between soil profile groups within each floodplain. To meet the assumptions of normality, TOC stocks were log-transformed and TOC1000 was square-root transformed. Finally, two-level nested ANOVAs were performed to test the effect of human-impact 


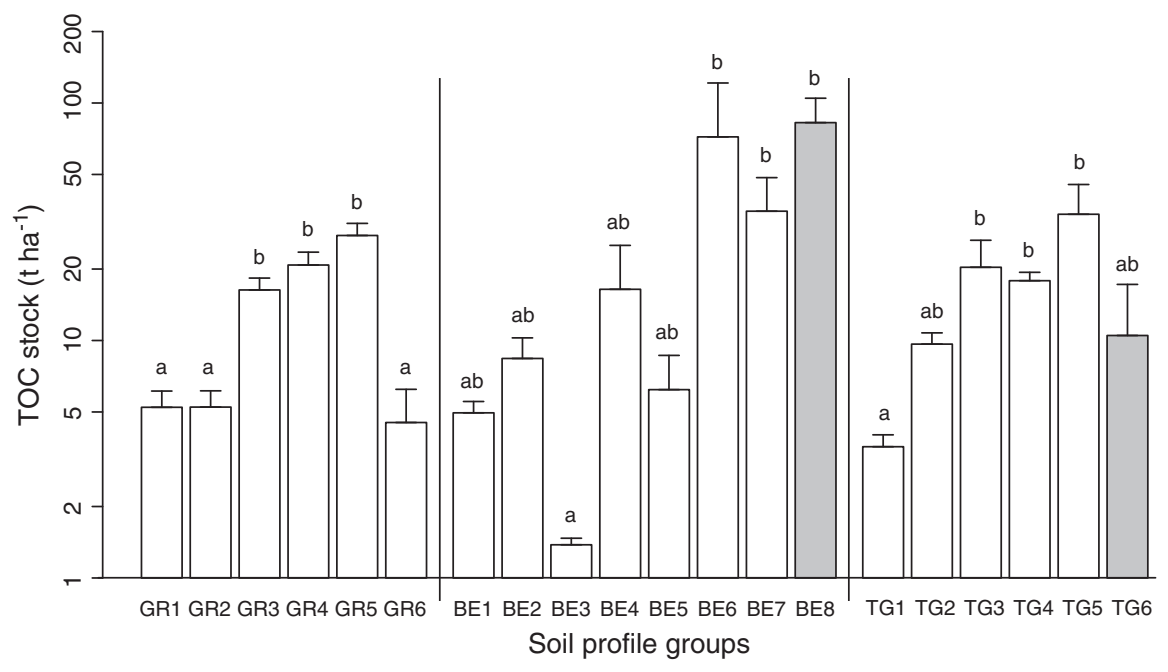

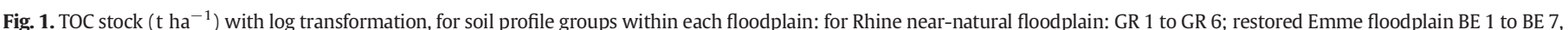

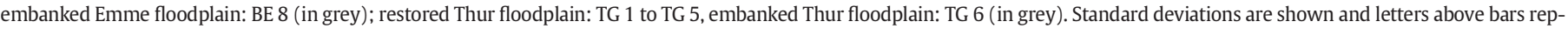
resent results from analysis of variance (one-way ANOVA calculated within each floodplain separately followed by Tukey Post-hoc tests).

(restoration and embanking) on carbon storage and SOM stabilisation parameters. The first level corresponds to two floodplains (Emme/ Thur), and the second level to the state of the floodplain (embanked/restored sections within each floodplain). For all tests performed with Statistica 11, levels of statistical significance were as follows: ns $=$ not significant, ${ }^{*} \mathrm{P}<0.05,{ }^{* *} \mathrm{P}<0.01$.

\section{Results}

\subsection{Carbon stocks, SOM stabilisation and soil properties}

Data that reflect carbon storage (carbon stocks) and SOM stabilisation in the soil profile groups that composed the three studied floodplains are presented in Appendix B and correspond to our response variables. TOC500 and TOC1000, as well as TOC250 and WSA parameters were highly correlated (Pearson correlation coefficients $\mathrm{r}^{2}>0.81$ ) thus only TOC1000 and WSA were considered for further analyses in order to avoid co-linearity.

The different soil properties for the soil profile groups that composed the three studied floodplains are shown in Appendix $C$ and these properties are our predictor variables. As the sand and the silt contents were highly correlated variables (Pearson correlation coefficient $\mathrm{r}^{2}=-0.98$ ), only the silt content was taken into account for further consideration.

\subsection{Dependency between carbon storage, SOM parameters and soil properties in the different floodplains}

Multivariate regression analysis showed a significant overall dependency between the response variables and the predictor variables $(\mathrm{P}<0.01)$. Indeed, all the soil properties except presence of hydromorphic features and total soil depth significantly contributed to explain this dependency. The results of Multivariate Analysis of Dependency between each response and predictor variables are as follows: the TOC stock was positively influenced by the clay content $(\mathrm{P}<0.01)$ and by the total iron content $(\mathrm{P}<0.05)$, while the $\mathrm{CaCO}_{3}$ content $(\mathrm{P}<0.01)$ and the silt content $(\mathrm{P}<0.01)$ negatively influenced the TOC stock (summary statistics for the regression analysis: adjusted $\mathrm{R}^{2}=0.412$ ). Moreover, the TOC1000 was negatively influenced by the total iron content, alluvial index $(\mathrm{P}<0.01)$ and $\mathrm{CaCO}_{3}$ content $(\mathrm{P}<0.05$; summary statistics for the regression analysis: adjusted $\left.\mathrm{R}^{2}=0.216\right)$. WSA was positively influenced by the total iron content $(\mathrm{P}<0.01)$, by the

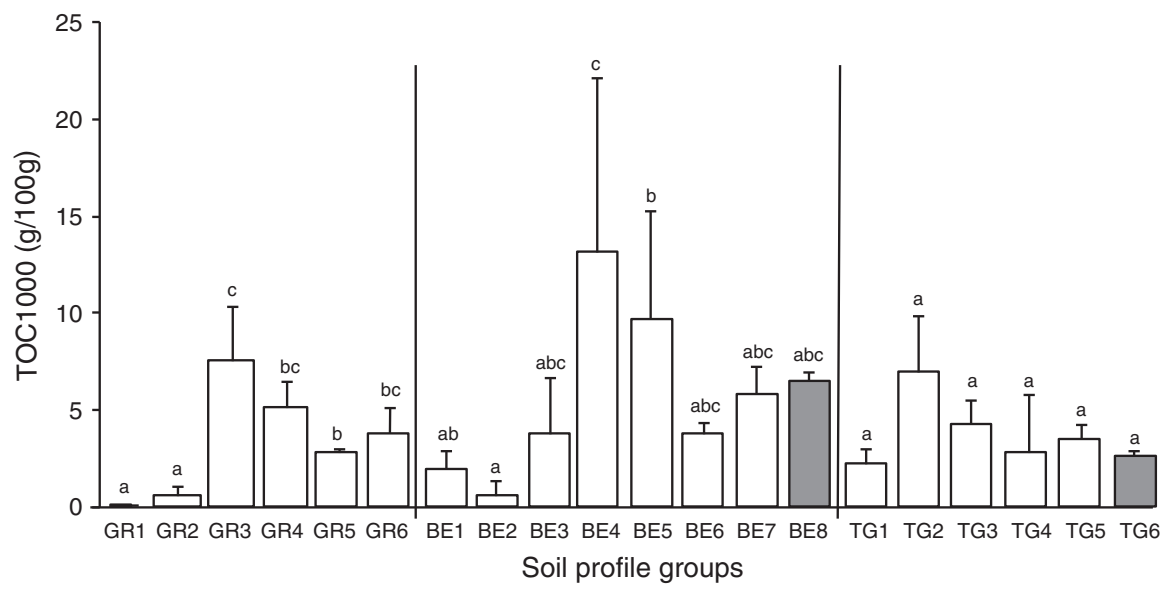

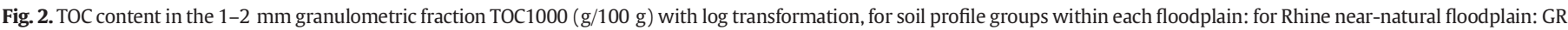

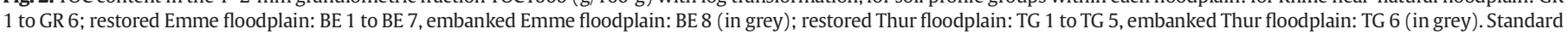

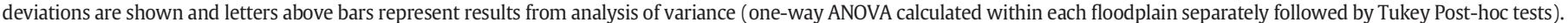




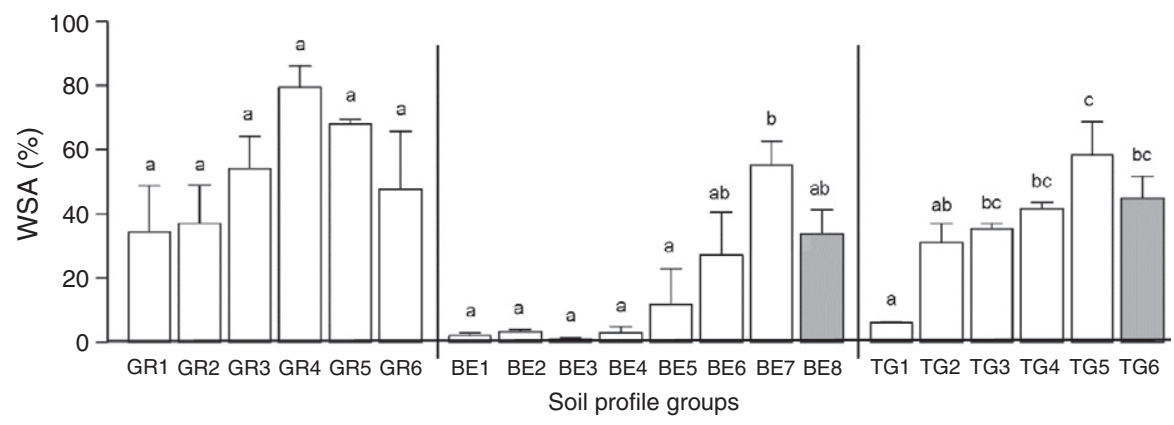

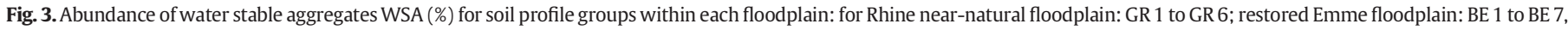

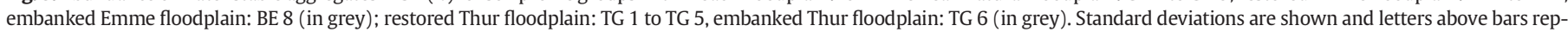
resent results from analysis of variance (one-way ANOVA calculated within each floodplain separately followed by Tukey Post-hoc tests).

$\mathrm{CaCO}_{3}$ content $(\mathrm{P}<0.05)$ and negatively affected by the alluvial index $(\mathrm{P}<0.05$; summary statistics for the regression analysis: adjusted $\left.\mathrm{R}^{2}=0.568\right)$. MWD was positively influenced by the clay content $(\mathrm{P}<0.01)$ and by total soil depth $(\mathrm{P}<0.05$; summary statistics for the regression analysis: Adjusted $\left.\mathrm{R}^{2}=0.361\right)$.

\subsection{Carbon storage and SOM stabilisation parameters in soil profile groups within each floodplain}

Mean TOC stocks ranged from 1.67 (GR 6) to $34.48 \mathrm{t} \mathrm{ha}^{-1}$ (GR 5) in the near-natural Rhine floodplain (Fig. 1). Mean TOC stocks were significantly lower in the GR 1, GR 2, GR 6 than in GR 3, GR 4, and GR 5 soil profiles. TOC stocks ranged from 0.80 (BE 4) to $169.56 \mathrm{t} \mathrm{ha}^{-1}$ (BE 6) within the restored Emme floodplain. In this floodplain, TOC stocks were significantly lower in $\mathrm{BE} 3$ than in $\mathrm{BE} 6, \mathrm{BE} 7$, and $\mathrm{BE} 8$ (in the embanked section). TOC stocks recorded for the restored Thur floodplain ranged from 3.10 (TG 1) to $56.70 \mathrm{t} \mathrm{ha}^{-1}$ (TG 5) with significant lower TOC stocks in bare gravels TG 1 than in more developed soils in the restored section TG 3 (under reed canarygrass), TG 4 (under willow bushes), TG 5 (under ash forest). Finally, TOC stocks in the embanked section (TG 6) did not differ from those of the other soil profile groups.

TOC1000 showed a different pattern with significant differences among soil profile groups for the Rhine floodplain and the Emme floodplain (Fig. 2), but not for the Thur floodplain. In the near-natural floodplain, WSA ranged from 34 to $79 \%$ and showed no difference between soil profile groups (Fig. 3). MWD values varied from 0.30 to $1.86 \mathrm{~mm}$, with MWD in GR 1 significantly lower than in GR 4 (Fig. 4). In the restored Emme floodplain, WSA ranged from 2 to $79 \%$ and was significantly higher in BE 7 than in other soil profile groups, while BE 8 (in the embanked zone) showed an intermediate value. MWD values varied from 0.51 to $2.17 \mathrm{~mm}$ with lowest value in $\mathrm{BE} 3$ and highest value in BE 7. In this case, MWD was significantly higher in BE $8(1.91 \mathrm{~mm})$ than in BE $1(1.03 \mathrm{~mm})$ and $\mathrm{BE} 3(0.51 \mathrm{~mm})$, but was not statistically different in the other soil profile groups. In the restored Thur floodplain, WSA values ranged from 1 to $55 \%$ with abundance of water stable aggregates significantly lower in TG 1 than in the other soil profile groups. MWD ranged from 1.31 to $2.47 \mathrm{~mm}$ and were not different among soil profile groups.

\subsection{Carbon storage parameters in restored and embanked sections}

Overall, for carbon stocks, a clear difference between the Emme and the Thur floodplains was observed $(\mathrm{P}<0.05)$ as well as a difference between restored (20.7 tha $\mathrm{t}_{-1}$; Table 2 ) and embanked sections (82.7 $\mathrm{t}$ ha ${ }_{-1}$; Table 2 ) within the Emme floodplain $(\mathrm{P}<0.01)$. An interaction between the level of human-impact and the floodplain was noticed. As seen in Fig. 5, river restoration led to a significant decrease in carbon stocks for the Emme floodplain, whereas no effect was observed for the Thur floodplain.

Considering the TOC1000, no effect of restoration was observed between floodplain or between embanked and restored sections within each floodplain. Finally, considering WSA and MWD, significant differences were only observed between floodplains $(\mathrm{P}<0.01$ for WSA and $\mathrm{P}<0.05$ for MWD), but not between embanked and restored sections within each floodplain (Table 3 ).

\section{Discussion}

\subsection{Carbon storage and SOM stabilisation in near-natural floodplains}

In the near-natural floodplain, values of TOC stocks were lower compared to those mentioned by Cierjacks et al. (2010, 2011). These authors reported $41 \mathrm{t} \mathrm{ha}^{-1}$ for Ah soils under softwood forests, $48 \mathrm{t} \mathrm{ha}^{-1}$ for soils under hardwood forests and reached respectively 113 and $138 \mathrm{t} \mathrm{ha}^{-1}$ when these stock calculations took into account all the Cenriched subsoil horizons up to $1 \mathrm{~m}$ in depth. Wigginton et al. (2000)

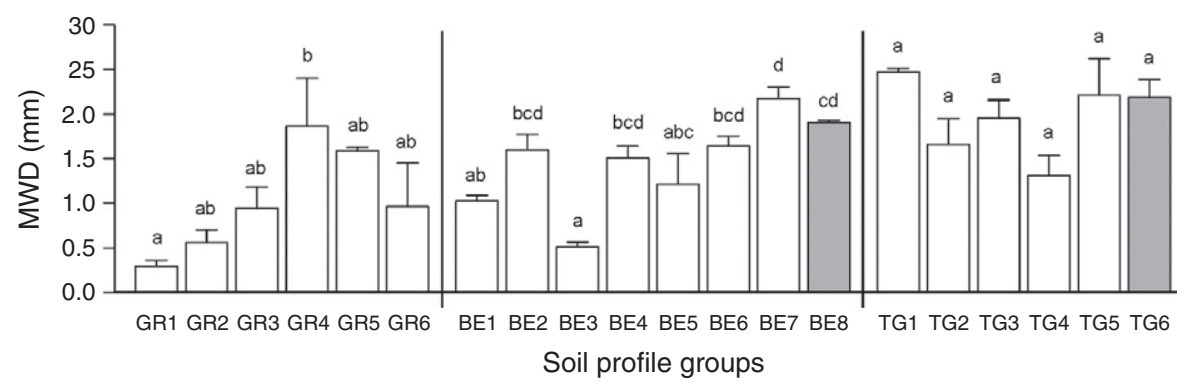

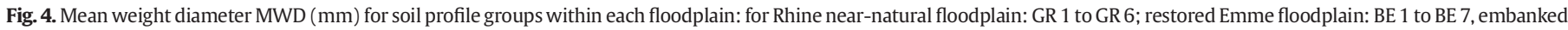

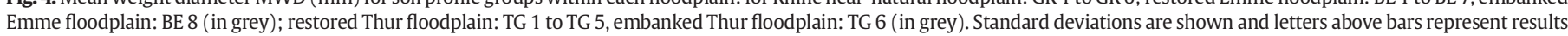
from analysis of variance (one-way ANOVA calculated within each floodplain separately followed by Tukey Post-hoc tests). 
Table 2

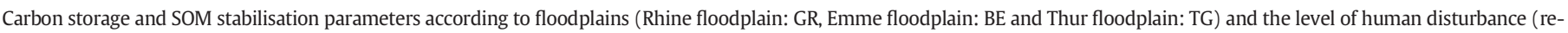
stored and embanked sections) for the Emme and Thur floodplains. Mean values ( \pm standard error) are indicated.

\begin{tabular}{|c|c|c|c|c|c|c|}
\hline \multicolumn{2}{|c|}{$\begin{array}{l}\text { Carbon storage and SOM } \\
\text { stabilisation parameters }\end{array}$} & \multicolumn{5}{|l|}{ Floodplains } \\
\hline \multirow[t]{2}{*}{ Name } & \multirow[t]{2}{*}{ Unit } & $\mathrm{GR}(\mathrm{N}=18)$ & $\mathrm{BE} 1$ to $\mathrm{BE} 7(\mathrm{~N}=21)$ & $\mathrm{BE} 8(\mathrm{~N}=3)$ & TG 1 to $\mathrm{TG} 5(\mathrm{~N}=15)$ & $\mathrm{TG} 6(\mathrm{~N}=3)$ \\
\hline & & Mean/std err & Restored mean/std err & Embanked mean/std err & Restored mean/std err & Embanked mean/std err \\
\hline StockTOC & t ha $^{-1}$ & $13.3 / 2.3$ & $20.7 / 8.1$ & $82.7 / 22.1$ & $17.1 / 3.5$ & $10.5 / 6.7$ \\
\hline TOC1000 & $\mathrm{g} / 100 \mathrm{~g}$ & $3.3 / 0.7$ & $5.5 / 1.2$ & $6.5 / 0.3$ & $3.9 / 0.6$ & $2.6 / 0.1$ \\
\hline MWD & $\mathrm{mm}$ & $1.0 / 0.2$ & $1.4 / 0.1$ & $1.9 / 0.02$ & $1.9 / 0.1$ & $2.2 / 0.2$ \\
\hline WSA & $\%$ & $53.4 / 5.6$ & $14.8 / 4.7$ & $33.7 / 7.6$ & $34.5 / 5.0$ & $44.8 / 7.0$ \\
\hline
\end{tabular}

reported TOC stock values even higher $\left(558.7 \mathrm{t} \mathrm{ha}^{-1}\right.$ per $\left.0.7 \mathrm{~m}\right)$ in minimally disturbed forested alluvial soils. These authors also reported an increase in WAS abundance along a soil evolution gradient. We found the same pattern along the soil evolution gradient.

\subsection{Soil properties influencing carbon storage and SOM stabilisation}

We demonstrated that, according to our first hypothesis, carbon storage and SOM stabilisation parameters are related to soil properties. Apart from total soil depth and hydromorphic features, all soil properties contribute to explain the carbon storage in terms of TOC stocks. Overall we found that, in all floodplains, both particle-size distribution (especially clay content) and chemical composition (total iron) of the mineral fraction positively affects TOC stock. These results confirm those already published by Bechtold and Naiman (2006) in a semiarid floodplain. These authors concluded that carbon storage in sandy soils is strongly related to fine particles' concentration. In our study, an increase of $\mathrm{CaCO}_{3}$ content led to a decrease in all carbon storage and SOM stabilisation parameters, except for MWD. Thus, $\mathrm{CaCO}_{3}$ content characterized the floodplain and could then reflect other environmental factors related to the floodplain (such as floodplain morphology, frequency of calcareous deposits by floods or vegetation cover) and could have an indirect effect on carbon storage. Other properties such as total soil depth also influenced carbon storage and SOM stabilisation parameters and especially the TOC in the 1-2 mm granulometric pool. This may be due to the soil evolution gradient within each floodplain, from bare soils to well-developed soils under forests, already described by Viereck et al. (1993) in different rivers of North America. In our case, the mechanisms of SOM stabilisation by aggregate formation (as

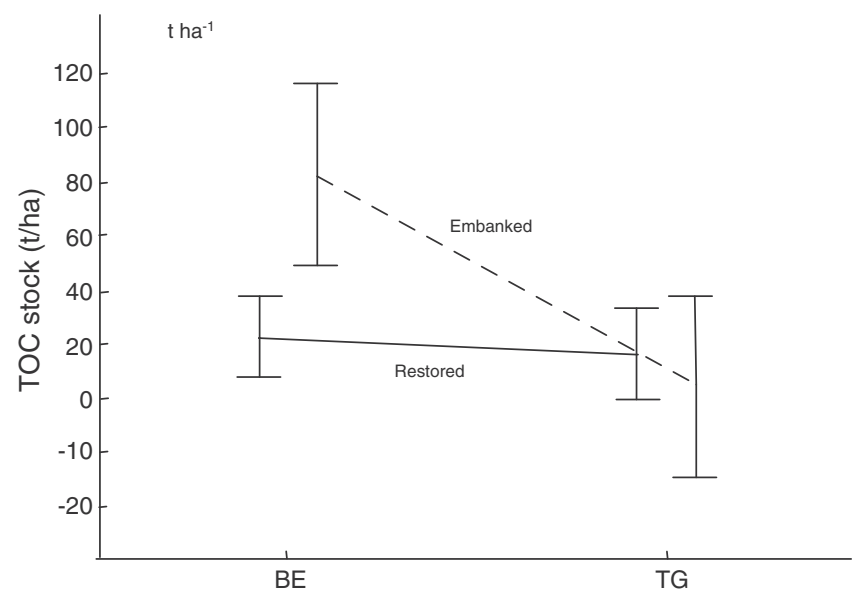

Fig. 5. Results of the two-level nested ANOVA's testing the "level of human disturbance" (restored and embanked sections) on the TOC stock $\left(\mathrm{t} \mathrm{ha}^{-1}\right)$ parameter. The first level corresponds to two floodplains (BE-Emme floodplain/TG-Thur floodplain, and the second level to the state of the floodplain embanked (dash line)/restored (solid line) sections within each floodplain). Significance of the model $\mathrm{P}=0.005^{* *}$. shown by MWD) was influenced by clay content, whereas WSA was surprisingly not. Total iron content also contributed to a better SOM stabilisation by playing an important role as stabilising component and binding organic and minerals particles, and thus increasing WSA and MWD values, as already confirmed by Bullinger-Weber et al. (2007) in calcareous-rich alluvial soils.

\subsection{Variability of carbon storage and SOM stabilisation within each floodplain}

According to our second hypothesis, we showed that soil profile groups defined by morphological criteria discriminate carbon storage and SOM stabilisation within each floodplain. In the Rhine near-natural floodplain, the high variability of TOC stock and SOM stabilisation demonstrates the inherent heterogeneity of alluvial soil systems. Indeed, we showed that an increase of TOC stocks follows a soil gradient evolution from mineral bare alluvial soils to more stabilised soils and a hydric functioning (soils with hydromorphic features). Our results confirmed that SOM in the uppermost humic layers increased during the alluvial soil formation as previously demonstrated by Van Cleve et al. (1993). These authors revealed that, in a natural floodplain, the increasing amounts of soil organic carbon were closely tied to the influence of vegetation and reflected SOM accumulation in soil profiles with advancing plant succession across a 200-year vegetation development sequence.

In alluvial soils without hydromorphic features, we demonstrated a significant increase of TOC stock and MWD from bare soils and to the well-developed and drained stabilised soils. This increase has already been observed in another near-natural Swiss floodplain under two different types of softwood forest (willow shrubs and alders; BullingerWeber et al., 2007). Onweremadu et al. (2010) also showed that MWD values increase from soils proximal to the river to the floodplain in South Nigeria (from 0.76 to $2.88 \mathrm{~mm}$ ). However, in hydromorphic soils, our data provide contradictory evidence on the effect of excess water on carbon quantities. As assessed in the literature, saturation by water should lead to a slow mineralization of fresh organic matter and thus contribute to an increase of TOC content (Schwartz and Namri, 2002). Our results did not support this hypothesis since low TOC stocks were observed in hydromorphic soils. This could be explained by differences in vegetation types as fewer trees and more herbaceous plants were found in the hydromorphic lateral branches where seasonal fluctuations of the water table lead to organic matter mineralisation (field observation).

In both restored sections, the variability of carbon storage and SOM stabilisation has increased compared to embanked sections used as references, and can be explained by the higher diversity of soil profile groups within restored sections compared to embanked sections where a single soil profile group is present. Previous researches performed on the Thur River have demonstrated that the river widening has increased soil diversity (Fournier et al., 2012) and the most striking changes occurred where post-restoration fluvial dynamics created diverse and dynamic pattern of soils (Fournier et al., 2013). In addition, Samaritani et al. (2011) showed that the Thur restored section exhibited 
Table 3

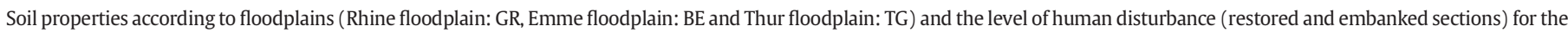
Emme and Thur floodplains. Mean values ( \pm standard error) are indicated.

\begin{tabular}{|c|c|c|c|c|c|c|}
\hline \multicolumn{2}{|l|}{ Soil properties } & \multicolumn{5}{|l|}{ Floodplains } \\
\hline \multirow[t]{2}{*}{ Name } & \multirow[t]{2}{*}{ Unit } & $\mathrm{GR}(\mathrm{N}=18)$ & $\mathrm{BE} 1$ to $\mathrm{BE} 7(\mathrm{~N}=21)$ & $\mathrm{BE} 8(\mathrm{~N}=3)$ & TG 1 to TG $5(\mathrm{~N}=15)$ & TG $6(\mathrm{~N}=3)$ \\
\hline & & Mean/std err & Restored mean/std err & Embanked mean/std err & Restored mean/std err & Embanked mean/std err \\
\hline Clay & $\%$ & $4.2 / 1.0$ & $6.0 / 1.1$ & $9.6 / 0.9$ & $11.8 / 1.2$ & $12.1 / 1.6$ \\
\hline Silt & $\%$ & $45.0 / 4.4$ & $15.7 / 2.7$ & $23.2 / 2.2$ & $33.5 / 4.0$ & $32.3 / 3.8$ \\
\hline $\mathrm{CaCO}_{3}$ & $\%$ & $23.4 / 0.7$ & $16.7 / 0.4$ & $11.2 / 1.5$ & $36.7 / 1.2$ & $39.1 / 0.2$ \\
\hline Total iron & $\mathrm{g} / 100 \mathrm{~g}$ & $3.1 / 0.1$ & $1.5 / 0.1$ & $2.5 / 0.03$ & $1.5 / 0.1$ & $1.5 / 0.04$ \\
\hline Hydro & Binary & $0.3 / 0.1$ & $0.14 / 0.08$ & $0 / 0$ & $0.47 / 0.13$ & $1 / 0$ \\
\hline Alluvial index & Number/cm & $0.1 / 0.02$ & $0.31 / 0.09$ & $0.09 / 0$ & $0.26 / 0.1$ & $0.05 / 0$ \\
\hline Total depth & $\mathrm{cm}$ & $52.9 / 8.4$ & $45 / 10$ & $15 / 3$ & $53 / 10$ & $108 / 4$ \\
\hline
\end{tabular}

both a larger range and a higher heterogeneity of organic $C$ pools (microbial $\mathrm{C}$ and water extractable organic $\mathrm{C}$ ) than the embanked section. Cierjacks et al. (2010) also highlighted that a restoration project could affect organic carbon storage by the creation of pioneer stages, such as bare alluvial soils. By contrast, Bruland and Richardson (2005) and Unghire et al. (2011) reported a homogenisation of SOM distribution (with a lack of patches of high or low concentration) in restored floodplains and concluded that the way the restoration projects have been conducted (rerouting the prior river to a more sinuous channel, vegetation and soil scraping, soil mixing and redistribution) can explain the lower SOM variability within restored floodplains compared to the unrestored floodplains.

\subsection{Impact of river restoration on carbon storage and SOM stabilisation}

We demonstrated that the overall effect of river restoration was different on the carbon storage and SOM stabilisation depending on the floodplain in question: i.e. a decrease for the Emme floodplain and no effect for the Thur floodplain. This different behaviour could be partly due to differences in vegetation composition in the embanked sections used as references. In the Emme floodplain, the mature forest was removed and replaced by pioneer vegetation that could decrease the amount of litter input and then the amount of organic matter incorporated in alluvial soils. Unghire et al. (2011) also highlighted that the replacement of tree canopy around the river by early floodplain grass and forb communities with juvenile trees contributes to the decrease of SOM in restored floodplains. On the contrary, in the Thur floodplain, where a pasture was replaced by various pioneer communities (mainly herbaceous and bush communities), no impact of restoration on carbon storage and SOM stabilisation was noticed.

Due to the slow development of post-restoration soils, the time elapsed since restoration was started has been taken into account to interpret the impact of river restoration on carbon storage and SOM stabilisation. For example, Unghire et al. (2011) concluded that 45 years since the beginning of restoration have not been sufficient for the ecosystem to recover from the disturbance and to develop patterns of spatial variability comparable with natural riparian wetlands. In productive and regularly inundated systems such as salt marshes, Craft et al. $(2002,2003)$ estimated that between 30 and 150 years are needed to accumulate pools of SOM equivalent to those of natural systems. In both restored floodplains, despite the short time elapsed since restoration was started ( 5 years in the case of the Thur River and 20 years in the case of the Emme River) some trends were clearly identifiable. In both floodplains, river restoration has increased the variability of soil morphology, carbon storage and SOM stabilisation within the restored section (compared to embanked section).

It is problematic to generalize our findings because research documenting the impacts of river restoration on carbon storage and SOM stabilisation is sparse and provides contradictory conclusions. According to Cierjacks et al. (2010) a restoration project could result in gains or in decreases of organic carbon in terms of stocks. Other researches demonstrated that soil properties and spatial patterns could be negatively affected by restoration activities, potentially hindering the development and function of ecosystems (Bruland and Richardson, 2005; Unghire et al., 2011). These authors noticed a decrease in the mean of SOM and a loss of SOM spatial heterogeneity in a restored floodplain. Unghire et al. (2011) suggested that these changes are the strongest evidences of disturbance associated with restoration activities.

The contradictory findings about the impact of restoration on carbon storage and SOM stabilisation and on their spatial variability reinforce the conclusion of Bruland and Richardson (2005). These authors highlighted that patterns of soil property variability, including the SOM pattern, are complex in natural and restored wetlands and could reflect a site-specific nature of spatial variability, in which unique geologic, hydrologic, vegetative, and land-use histories may interact to create unique patterns of spatial variability.

In addition, the way the restoration project was conducted has to be taken into account to explain the diametrically opposite impacts of river restoration on carbon storage and SOM stabilisation. Restoration projects which require a high degree of earthmoving and homogenization of soils as well as vegetation scraping lead to a decrease of SOM and a loss of SOM spatial variability (Unghire et al., 2011). By contrast, other restoration activities (river widening by embankment removal implying less soil manipulations) lead to a larger range and a higher heterogeneity of organic C pools (Samaritani et al., 2011) and seem to re-create SOM pattern characteristics in natural floodplains.

\section{Conclusion}

Recent research projects conducted in floodplains have used different indicators to predict carbon storage. For example, Cierjacks et al. (2010) proposed the inclusion of spatial and geomorphological variables rather than potentially man-made vegetation types for modelling the amounts and distribution of carbon stocks in floodplains. Indeed, these authors concluded that, in the Danube floodplain, vegetation distribution does not indicate the conditions of sedimentation and soil carbon sequestration over the time in question of soil carbon stock development. Moreover, Cierjacks et al. (2011) showed that the soil organic stocks increased significantly with distance to the next channel along a longitudinal gradient. By contrast, Drouin et al. (2011) did not detect a significant pattern of the spatial distribution of total organic carbon in alluvial soils of active floodplains even using a high precision digital elevation model to define floodplain micro-topography.

Our results confirm that soil morphology inherently contains structural and functional information on floodplain ecosystems as demonstrated previously by Fournier et al. (2013) on the Thur floodplain. We showed that soil morphology and some related soil properties ( particle-size distribution, total iron and $\mathrm{CaCO}_{3}$ contents of the uppermost humic layer) are also adequate indicators explaining the variability of carbon storage and SOM stabilisation in floodplains differing in the level of human disturbance (i.e. near-natural, embanked and restored 
floodplains). As soil morphology reacts fast and clearly to river restoration, this indicator could also be easily used to assess the impact of restoration on carbon storage. This is in accordance with Cole and Kentula (2011), who pointed out that soil descriptions are of great important as an indicator of wetland assessment.

\section{Acknowledgements}

This research was supported by the MHV programme of the Swiss National Science Foundation (subside n PMPDP2_123031). The authors would like to thank the CCES RECORD Catchment project, as well as Simona Pfund, Vincent Feissli, Nathalie Moreira and Coraline Sahin for their help during the study, and Dr. Robert Mills for the language revision.

\section{References}

Bai, J.H., Hua, O.Y., Wei, D., Zhu, Y.M., Zhang, X.L., Wang, Q.G., 2005. Spatial distribution characteristics of organic matter and total nitrogen of marsh soils in river marginal wetlands. Geoderma 124 (1-2), 181-192.

Ballantine, K., Schneider, R., 2009. Fifty-five years of soil development in restored freshwater depressional wetlands. Ecol. Appl. 19 (6), 1467-1480.

Appendix A. Descriptions of soil clusters resulting from hierarchical classifications (preliminary soil survey, not shown) for the three studied floodplains (Rhine floodplain: GR 1 to GR 6; Emme floodplain: BE 1 to BE 8; Thur floodplain: TG 1 to TG 6): frequency of each soil group (\%), total depth of the soil profile (cm), total number of the layers in the soil profile, number of layers of different texture, dominant texture of the layers ( $\mathrm{S}=$ sandy texture; IS = loamy-sand texture), absence or presence of hydromorphic features (0/1), coarse elements ( $>2 \mathrm{~mm}$; \%), presence of roots in the uppermost humic layer $(0=$ no root, $1=$ some roots, $2=$ roots abundant $)$. Mean values ( \pm standard deviation) are indicated.

\begin{tabular}{|c|c|c|c|c|c|c|c|c|}
\hline Soil clusters & Frequency (\%) & Total depth $(\mathrm{cm})$ & Number of layers & Number of textural layers & Texture of layers & Hydromorphic features & Coarse elements (\%) & Roots \\
\hline GR 1 & 5 & $12( \pm 3)$ & $1( \pm 0)$ & $1( \pm 0)$ & $\mathrm{S}$ & 0 & $0( \pm 0)$ & $1( \pm 0)$ \\
\hline GR 2 & 42 & $5( \pm 3)$ & $1( \pm 0)$ & $1( \pm 0)$ & $\mathrm{S}$ & 0 & $47( \pm 31)$ & $0( \pm 0)$ \\
\hline GR 3 & 31 & $32( \pm 15)$ & $3( \pm 0.6)$ & $1( \pm 0)$ & $\mathrm{S}$ & 0 & $1( \pm 0)$ & $1( \pm 1)$ \\
\hline GR 4 & 5 & $56( \pm 8)$ & $4( \pm 0)$ & $2( \pm 0)$ & S-IS & 0 & $0( \pm 0)$ & $2( \pm 0)$ \\
\hline GR 5 & 8 & $82( \pm 0)$ & $4( \pm 0.6)$ & $2( \pm 0)$ & S-IS & 1 & $0( \pm 0)$ & $2( \pm 0)$ \\
\hline GR 6 & 9 & $92( \pm 13)$ & $4( \pm 0.7)$ & $2( \pm 0)$ & S-IS & 2 & $0( \pm 0)$ & $2( \pm 0)$ \\
\hline BE 1 & 24 & $1( \pm 0)$ & $1( \pm 0)$ & $1( \pm 0)$ & $S$ & 0 & $83( \pm 9)$ & $0( \pm 0)$ \\
\hline BE 2 & 10 & $1( \pm 0)$ & $1( \pm 0)$ & $1( \pm 0)$ & $S$ & 0 & $82( \pm 9)$ & $0( \pm 0)$ \\
\hline BE 3 & 14 & $10( \pm 6)$ & $2( \pm 0.6)$ & $1( \pm 0)$ & $\mathrm{S}$ & 0 & $64( \pm 19)$ & $0( \pm 0)$ \\
\hline BE 4 & 11 & $101( \pm 17)$ & $4( \pm 1.3)$ & $4( \pm 1)$ & IS & 0 & $3( \pm 0.4)$ & $1( \pm 1)$ \\
\hline BE 5 & 15 & $75( \pm 36)$ & $5( \pm 3.1)$ & $5( \pm 3)$ & S-IS & 1 & $5( \pm 4)$ & $1( \pm 1)$ \\
\hline BE 6 & 15 & $21( \pm 11)$ & $2( \pm 0.6)$ & $1( \pm 0)$ & S-IS & 0 & $6( \pm 14)$ & $1( \pm 0.5)$ \\
\hline BE 7 & 10 & $49( \pm 28)$ & $3( \pm 1.2)$ & $3( \pm 1)$ & S-IS & 0 & $2( \pm 4)$ & $1( \pm 0.5)$ \\
\hline BE 8 & 1 & $15( \pm 6)$ & $1( \pm 0.6)$ & $1( \pm 0)$ & $\mathrm{S}$ & 0 & $3( \pm 3)$ & $1( \pm 0)$ \\
\hline TG 1 & 10 & $1( \pm 0)$ & $1( \pm 0)$ & $1( \pm 0)$ & $\mathrm{S}$ & 0 & $90( \pm 9)$ & $0( \pm 0.5)$ \\
\hline TG 2 & 13 & $3( \pm 7)$ & $1( \pm 0)$ & $1( \pm 0)$ & $\mathrm{S}$ & 0 & $83( \pm 29)$ & $1( \pm 0.5)$ \\
\hline TG 3 & 25 & $24( \pm 19)$ & $2( \pm 0.5)$ & $2( \pm 0.5)$ & S-IS & 0 & $41( \pm 22)$ & $2( \pm 0.5)$ \\
\hline TG 4 & 19 & $100( \pm 27)$ & $3( \pm 1)$ & $2( \pm 0.5)$ & IS & 0 & $1( \pm 2)$ & $2( \pm 0.5)$ \\
\hline TG 5 & 17 & $104( \pm 13)$ & $2( \pm 0.5)$ & $2( \pm 0.5)$ & IS & 1 & $0( \pm 0)$ & $1( \pm 0.5)$ \\
\hline TG 6 & 17 & $113( \pm 26)$ & $3( \pm 1)$ & $3( \pm 0.5)$ & IS & 1 & $1( \pm 3)$ & $2( \pm 0.5)$ \\
\hline
\end{tabular}

Appendix B. Carbon storage and SOM stabilisation parameters for each soil profile group (final study): bulk density ( $\left.\mathbf{t} \mathrm{m}^{-3}\right)$, total organic carbon content of the bulk soil (TOC, in $\mathrm{g} / \mathbf{1 0 0} \mathrm{g}$ ), uppermost humic thickness (cm), total organic carbon stock in bulk soil (TOC stock, in $\mathrm{t} \mathrm{ha}^{-1}$ ), total organic carbon content in the 1-2 cm fraction (TOC1000, in $\mathrm{g} / 100 \mathrm{~g}$ ), mean weight diameter of macro-aggregates (MWD, in mm), abundance of water stable aggregates (WSA, in \%). Mean values ( \pm standard deviation) are indicated.

\begin{tabular}{|c|c|c|c|c|c|c|c|c|c|}
\hline $\begin{array}{l}\text { Soil profile } \\
\text { group }\end{array}$ & $\begin{array}{l}\text { Bulk density } \\
\left(\mathrm{t} \mathrm{m}^{-3}\right)\end{array}$ & $\begin{array}{l}\text { TOC } \\
(\mathrm{g} / 100 \mathrm{~g})\end{array}$ & $\begin{array}{l}\text { TOC stock } \\
\left(\mathrm{t} \mathrm{ha}^{-1}\right)\end{array}$ & $\begin{array}{l}\text { Thickness of upper-most } \\
\text { humic layer }(\mathrm{cm})\end{array}$ & $\begin{array}{l}\text { TOC1000 } \\
(\mathrm{g} / 100 \mathrm{~g})\end{array}$ & $\begin{array}{l}\text { TOC500 } \\
(\mathrm{g} / 100 \mathrm{~g})\end{array}$ & $\begin{array}{l}\text { TOC250 } \\
(\mathrm{g} / 100 \mathrm{~g})\end{array}$ & $\begin{array}{l}\text { MWD } \\
(\mathrm{mm})\end{array}$ & $\begin{array}{l}\text { WSA } \\
(\%)\end{array}$ \\
\hline GR 1 & $1.51( \pm 0.4)$ & $0.48( \pm 0.1)$ & $5.23( \pm 1.6)$ & $8( \pm 3)$ & $0.01( \pm 0)$ & $0.33( \pm 0)$ & $0.23( \pm 0)$ & $0.30( \pm 0.1)$ & $34( \pm 25)$ \\
\hline GR 2 & $1.23( \pm 0.1)$ & $0.79( \pm 0.3)$ & $5.24( \pm 1.6)$ & $6( \pm 1)$ & $0.59( \pm .4)$ & $0.60( \pm 0.1)$ & $0.48( \pm 0.1)$ & $0.57( \pm 0.2)$ & $37( \pm 21)$ \\
\hline GR 3 & $0.95( \pm 0)$ & $5.48( \pm 1.5)$ & $16.32( \pm 3.5)$ & $3( \pm 1)$ & $7.48( \pm 2.8)$ & $6.01( \pm 2.5)$ & $4.97( \pm 2.6)$ & $0.94( \pm 0.4)$ & $54( \pm 18)$ \\
\hline GR 4 & $0.85( \pm 0)$ & $5.41( \pm 1.6)$ & $20.79( \pm 4.8)$ & $5( \pm 1)$ & $5.08( \pm 1.4)$ & $5.39( \pm 2.2)$ & $4.86( \pm 1.6)$ & $1.86( \pm 0.9)$ & $79( \pm 12)$ \\
\hline GR 5 & $0.99( \pm 0.1)$ & $2.83( \pm 0.8)$ & $27.69( \pm 6)$ & $10( \pm 0)$ & $2.74( \pm 0.2)$ & $2.63( \pm 0.4)$ & $2.74( \pm 0.9)$ & $1.59( \pm 0.1)$ & $68( \pm 3)$ \\
\hline GR 6 & $0.98( \pm 0)$ & $0.46( \pm 0.3)$ & $4.51( \pm 3)$ & $10( \pm 0)$ & $3.78( \pm 1.3)$ & $3.27( \pm 0.3)$ & $2.85( \pm 0.5)$ & $0.96( \pm 0.9)$ & $48( \pm 31)$ \\
\hline BE 1 & $1.95( \pm 0)$ & $0.26( \pm 0)$ & $4.96( \pm 1)$ & $10( \pm 2)$ & $1.86( \pm 1)$ & $0.89( \pm 0.3)$ & $0.21( \pm 0.1)$ & $1.03( \pm 0.1)$ & $2( \pm 1.4)$ \\
\hline BE 2 & $1.95( \pm 0)$ & $0.44( \pm 0)$ & $8.40( \pm 3.2)$ & $10( \pm 4)$ & $0.57( \pm 0.7)$ & $0.5( \pm 0.5)$ & $0.25( \pm 0)$ & $1.60( \pm 0.3)$ & $3( \pm 1.2)$ \\
\hline BE 3 & $1.49( \pm 0.1)$ & $0.11( \pm 0)$ & $1.38( \pm 0.2)$ & $9( \pm 1)$ & $3.77( \pm 2.9)$ & $1.15( \pm 1.5)$ & $0.12( \pm 0.1)$ & $0.51( \pm 0.1)$ & $1( \pm 0.4)$ \\
\hline BE 4 & $1.35( \pm 0.1)$ & $0.37( \pm 0.2)$ & $16.44( \pm 15)$ & $28( \pm 24)$ & $13.12( \pm 9)$ & $11.5( \pm 10)$ & $1.12( \pm 1.5)$ & $1.51( \pm 0.2)$ & $3( \pm 3)$ \\
\hline BE 5 & $1.42( \pm 0.1)$ & $0.73( \pm 0.9)$ & $6.21( \pm 4.2)$ & $11( \pm 11)$ & $9.63( \pm 5.6)$ & $6.03( \pm 3.1)$ & $0.87( \pm 1)$ & $1.21( \pm 0.6)$ & $12( \pm 19)$ \\
\hline BE 6 & $1.49( \pm 0.3)$ & $2.08( \pm 1.8)$ & $72.05( \pm 86)$ & $21( \pm 13)$ & $3.71( \pm 0.6)$ & $3.77( \pm 1.1)$ & $2.19( \pm 2)$ & $1.64( \pm 0.2)$ & $27( \pm 23)$ \\
\hline BE 7 & $1.26( \pm 0.1)$ & $4.05( \pm 1.5)$ & $35.03( \pm 23)$ & $8( \pm 5)$ & $5.73( \pm 1.5)$ & $6.70( \pm 1.7)$ & $5.30( \pm 0.9)$ & $2.17( \pm 0.2)$ & $55( \pm 13)$ \\
\hline BE 8 & $1.38( \pm 0)$ & $5.62( \pm 1.9)$ & $82.70( \pm 38)$ & $10( \pm 2)$ & $6.48( \pm 0.5)$ & $5.79( \pm 0.5)$ & $4.44( \pm 0.2)$ & $1.91( \pm 0)$ & $34( \pm 13)$ \\
\hline TG 1 & $1.95( \pm 0)$ & $1.83( \pm 0.4)$ & $3.57( \pm 0.7)$ & $1( \pm 0)$ & $2.23( \pm 0.7)$ & $1.09( \pm 0.5)$ & $0.57( \pm 0.4)$ & $2.47( \pm 0.1)$ & $6( \pm 0.3)$ \\
\hline TG 2 & $1.03( \pm 0.1)$ & $1.50( \pm 0.5)$ & $9.66( \pm 1.9)$ & $7( \pm 4)$ & $6.94( \pm 2.9)$ & $4.36( \pm 0.9)$ & $2.11( \pm 0.9)$ & $1.66( \pm 0.5)$ & $31( \pm 10)$ \\
\hline TG 3 & $1.17( \pm 0.1)$ & $2.44( \pm 0.2)$ & $20.34( \pm 11)$ & $7( \pm 4)$ & $4.18( \pm 1.3)$ & $3.84( \pm 2.4)$ & $2.27( \pm 1.7)$ & $1.96( \pm 0.4)$ & $35( \pm 3)$ \\
\hline TG 4 & $1.20( \pm 0.1)$ & $1.96( \pm 0.3)$ & $17.86( \pm 2.6)$ & $8( \pm 1)$ & $2.74( \pm 3)$ & $1.83( \pm 1.3)$ & $2.44( \pm 1.3)$ & $1.31( \pm 0.4)$ & $42( \pm 3)$ \\
\hline TG 5 & $1.22( \pm 0.1)$ & $2.37( \pm 1)$ & $34.02( \pm 20)$ & $15( \pm 13)$ & $3.44( \pm 0.7)$ & $3.15( \pm 0.7)$ & $3.39( \pm 1.6)$ & $2.21( \pm 0.7)$ & $58( \pm 18)$ \\
\hline TG 6 & $1.26( \pm 0.1)$ & $1.18( \pm 1)$ & $10.5( \pm 11.7)$ & $6( \pm 2)$ & $2.63( \pm 0.2)$ & $3.49( \pm 3)$ & $2.40( \pm 1)$ & $2.18( \pm 0.4)$ & $45( \pm 12)$ \\
\hline
\end{tabular}


Appendix C. Soil properties for each soil profile group (final study): clay, silt and sand content (\%), total carbonate content (CaCO ${ }_{3}$, in $\%$ ), total iron content ( $\mathrm{g} / \mathbf{1 0 0} \mathrm{g})$, absence or presence of hydromorphy features $(\mathbf{0} / 1)$, alluvial index corresponding to the total number of layers divided by the total depth of the soil profile, total depth of the soil profile (total depth in $\mathrm{cm})$. Mean values ( \pm standard deviation) are indicated.

\begin{tabular}{|c|c|c|c|c|c|c|c|c|c|}
\hline Soil profile group & Clay (\%) & Silt (\%) & Sand (\%) & $\mathrm{CaCO}_{3}(\%)$ & Total iron (g/100 g) & Hydro $(0 / 1)$ & Alluvial index & Total number of layers & Total depth $(\mathrm{cm})$ \\
\hline GR 1 & $1( \pm 0.3)$ & $35( \pm 8)$ & $52( \pm 10)$ & $28( \pm 1)$ & $2.9( \pm 0.2)$ & $0( \pm 0)$ & $0.2( \pm 0.05)$ & $1( \pm 0)$ & $5( \pm 2)$ \\
\hline GR 2 & $2( \pm 1.5)$ & $39( \pm 20)$ & $48( \pm 26)$ & $37( \pm 2)$ & $2.8( \pm 0.3)$ & $0( \pm 0)$ & $0.06( \pm 0)$ & $3( \pm 0)$ & $52( \pm 0)$ \\
\hline GR 3 & $6( \pm 0.8)$ & $29( \pm 18)$ & $62( \pm 22)$ & $39( \pm 4)$ & $2.7( \pm 0.1)$ & $1( \pm 0)$ & $0.16( \pm 0.08)$ & $2( \pm 0)$ & $17( \pm 12)$ \\
\hline GR 4 & $5( \pm 1.9)$ & $40( \pm 23)$ & $45( \pm 30)$ & $40( \pm 1)$ & $3.1( \pm 0.1)$ & $1( \pm 0)$ & $0.07( \pm 0.01)$ & $4( \pm 0)$ & $56( \pm 4)$ \\
\hline GR 5 & $6( \pm 03.7)$ & $24( \pm 9)$ & $66( \pm 11)$ & $40( \pm 1)$ & $3.7( \pm 0.1)$ & $0( \pm 0.6)$ & $0.04( \pm 0.01)$ & $4( \pm 1)$ & $93( \pm 10)$ \\
\hline GR 6 & $5( \pm 1.2)$ & $35( \pm 7)$ & $53( \pm 9)$ & $39( \pm 0)$ & $3.7( \pm 0.1)$ & $1( \pm 0)$ & $0.03( \pm 0)$ & $3( \pm 0)$ & $95( \pm 8)$ \\
\hline BE 1 & $3( \pm 0.3)$ & $11( \pm 4)$ & $86( \pm 5)$ & $17( \pm 1)$ & $1.4( \pm 0.2)$ & $0( \pm 0)$ & $1.0( \pm 0)$ & $1( \pm 0)$ & $1( \pm 0)$ \\
\hline BE 2 & $3( \pm 0.6)$ & $9( \pm 1)$ & $88( \pm 1)$ & $17( \pm 0)$ & $1.3( \pm 0.1)$ & $0( \pm 0.6)$ & $0.69( \pm 0.43)$ & $2( \pm 1.7)$ & $17( \pm 28)$ \\
\hline BE 3 & $2( \pm 0.3)$ & $5( \pm 2)$ & $94( \pm 2)$ & $16( \pm 2)$ & $1.2( \pm 0.1)$ & $0( \pm 0)$ & $0.24( \pm 0.01)$ & $2.3( \pm 0.6)$ & $10( \pm 3)$ \\
\hline $\mathrm{BE} 4$ & $3( \pm 1)$ & $11( \pm 4)$ & $86( \pm 4)$ & $18( \pm 2)$ & $1.3( \pm 0.2)$ & $0( \pm 0)$ & $0.04( \pm 0.01)$ & $4.3( \pm 0.6)$ & $110( \pm 0)$ \\
\hline BE 5 & $4( \pm 1.4)$ & $12( \pm 8)$ & $84( \pm 11)$ & $18( \pm 1)$ & $1.4( \pm 0.2)$ & $1( \pm 0.6)$ & $0.05( \pm 0.02)$ & $5( \pm 1)$ & $96( \pm 25)$ \\
\hline BE 6 & $10( \pm 6.5)$ & $27( \pm 16)$ & $64( \pm 22)$ & $16( \pm 2)$ & $1.9( \pm 0.4)$ & $0( \pm 0)$ & $0.06( \pm 0.03)$ & $1( \pm 0)$ & $21( \pm 13)$ \\
\hline BE 7 & $14( \pm 1)$ & $36( \pm 6)$ & $50( \pm 6)$ & $15( \pm 2)$ & $2.0( \pm 0.2)$ & $0( \pm 0)$ & $0.06( \pm 0.01)$ & $3.3( \pm 0.6)$ & $61( \pm 13)$ \\
\hline BE 8 & $10( \pm 1.6)$ & $23( \pm 4)$ & $67( \pm 4)$ & $11( \pm 3)$ & $2.5( \pm 0.1)$ & $0( \pm 0)$ & $0.09( \pm 0.01)$ & $1.3( \pm 0.6)$ & $15( \pm 6)$ \\
\hline TG 1 & $13( \pm 2.5)$ & $8( \pm 5)$ & $90( \pm 5)$ & $26( \pm 3)$ & $1.4( \pm 0.4)$ & $0( \pm 0)$ & $1.0( \pm 0)$ & $1( \pm 0)$ & $1( \pm 0)$ \\
\hline TG 2 & $13( \pm 6.3)$ & $12( \pm 15)$ & $86( \pm 16)$ & $27( \pm 3)$ & $1.4( \pm 0.1)$ & $0( \pm 0)$ & $0.14( \pm 0.12)$ & $3.3( \pm 1.5)$ & $28( \pm 10)$ \\
\hline TG 3 & $9( \pm 4.2)$ & $42( \pm 8)$ & $51( \pm 8)$ & $22( \pm 1)$ & $1.4( \pm 0.1)$ & $0( \pm 0)$ & $0.07( \pm 0.01)$ & $4( \pm 0)$ & $57( \pm 18)$ \\
\hline TG 4 & $15( \pm 7.1)$ & $62( \pm 6)$ & $33( \pm 8)$ & $20( \pm 1)$ & $1.7( \pm 0.2)$ & $0( \pm 0)$ & $0.05( \pm 0.02)$ & $3.6( \pm 0.6)$ & $86( \pm 30)$ \\
\hline TG 5 & $9( \pm 2.3)$ & $69( \pm 3)$ & $25( \pm 6)$ & $23( \pm 0)$ & $1.6( \pm 0.2)$ & $1( \pm 0)$ & $0.04( \pm 0.02)$ & $3.3( \pm 0.6)$ & $94( \pm 24)$ \\
\hline TG 6 & $12( \pm 2.8)$ & $75( \pm 6)$ & $20( \pm 8)$ & $22( \pm 1)$ & $1.5( \pm 0.1)$ & $1( \pm 0)$ & $0.05( \pm 0.01)$ & $5( \pm 1)$ & $108( \pm 8)$ \\
\hline
\end{tabular}

Barton, C., Nelson, E.A., Kolka, R.K., McLeod, K.W., Conner, W.H., Lakly, M., Martin, D., Wigginton, J., Trettin, C.C., Wisniewski, J., 2000. Restoration of a severely impacted riparian wetland system - The Pen Branch Project. Ecol. Eng. 15, 3-15.

Bechtold, J.S., Naiman, R.J., 2006. Soil texture and nitrogen mineralization potential across a riparian toposequence in a semi-arid savanna. Soil Biol. Biochem. 38 (6), 1325-1333.

Bechtold, J.S., Naiman, R.J., 2009. A quantitative model of soil organic matter accumulation during floodplain primary succession. Ecosystems 12 (8), 1352-1368.

Bernal, B., Mitsch, W.J., 2008. A comparison of soil carbon pools and profiles in wetlands in Costa Rica and Ohio. Ecol. Eng. 34 (4), 311-323.

Blazejewski, G.A., Stolt, M.H., Gold, A.J., Gurwick, N., Groffman, P.M., 2009. Spatial distribution of carbon in the subsurface of riparian zones. Soil Sci. Soc. Am. J. 73 (5), 1733-1740.

Bruland, G.L., Richardson, C.J., 2005. Spatial variability of soil properties in created, restored, and paired natural wetlands. Soil Sci. Soc. Am. J. 69 (1), 273-284.

Bullinger-Weber, G., Gobat, J.M., 2006. Identification of facies models in alluvial soil formation: the case of a Swiss alpine floodplain. Geomorphology 174, 181-195.

Bullinger-Weber, G., Le Bayon, R.C., Guenat, C., Gobat, J.M., 2007. Influence of some physicochemical and biological parameters on soil structure formation in alluvial soils. Eur. J. Soil Biol. 43 (1), 57-70.

Cabezas, A., Comin, F.A., 2010. Carbon and nitrogen accretion in the topsoil of the middle Ebro River floodplains (NE Spain): implications for their ecological restoration. Ecol. Eng. 36 (5), 640-652.

Carter, M.R., Gregorich, E.G., 2007. Soil Sampling and Methods of Analysis. CRC Press, Boca Raton.

Cierjacks, A., Kleinschmit, B., Babinsky, M., Kleinschroth, F., Markert, A., Menzel, M., Ziechmann, U., Schiller, T., Graf, M., Lang, F., 2010. Carbon stocks of soil and vegetation on Danubian floodplains. J. Plant Nutr. Soil Sci. 173 (5), 644-653.

Cierjacks, A., Kleinschmit, B., Kowarik, I., Graf, M., Lang, F., 2011. Organic matter distribution in floodplains can be predicted using spatial and vegetation structure data. River Res. Appl. 27 (8), 1048-1057.

Cole, C.A., Kentula, M.E., 2011. Monitoring and assessment - What to measure... and why. In: LePage, B.A. (Ed.), Wetlands. Springer Science + business Media, pp. 138-152.

Craft, C., Broome, S., Campbell, C., 2002. Fifteen years of vegetation and soil development after brackish-water marsh creation. Restor. Ecol. 10 (2), 248-258.

Craft, C., Megonigal, P., Broome, S., Stevenson, J., Freese, R., Cornell, J., Zheng, L., Sacco, J. 2003. The pace of ecosystem development of constructed Spartina alterniflora marshes. Ecol. Appl. 13 (5), 1417-1432.

Drouin, A., Saint-Laurent, D., Lavoie, L., Ouellet, C., 2011. High-precision elevation model to evaluate the spatial distribution of soil organic carbon in active floodplains. Wetlands 31 (6), 1151-1164

Fournier, B., Samaritani, E., Shrestha, J., Mitchell, E.A.D., Le Bayon, R.-C., 2012. Patterns of earthworm communities and species traits in relation to the perturbation gradient of a restored floodplain. Appl. Soil Ecol. 59, 87-95.

Fournier, B., Guenat, C., Bullinger-Weber, G., Mitchell, E.A.D., 2013. Spatio-temporal heterogeneity of riparian soil morphology in a restored floodplain. Hydrol. Earth Syst. Sci. 17 (10), 4031-4042.

Gallandat, J.D., Gobat, J.M., Roulier, C., 1993. Cartographie des zones alluviales d'importance nationale: rapport et annexes. Cahier de l'Environnement, 199. Office Fédéral de l'Environnement, des Forêts et du Paysage (OFEFP), Berne, Switzerland.

Gerber, E., Krebs, C., Murrell, C., Moretti, M., Rocklin, R., Schaffner, U., 2007. Exotic invasive knotweeds (Fallopia spp.) negatively affect native plant and invertebrate assemblages in European riparian habitats. Biol. Conserv. 141 (3), 646-654

Gerrard, J., 1987. Alluvial Soils. Hutchinson Ross, New York.
Giese, L.A., Aust, M.W., Trettin, C.C., Kolka, R.K., 2000. Spatial and temporal patterns of carbon storage and species richness in three South Carolina coastal plain riparian forests. Ecol. Eng. 15, 157-170.

Guenat, C., Bureau, F., Weber, G., Toutain, F., 1999. Initial stages of soil formation in a riparian zone: Importance of biological agents and lithogenic inheritance in the development of the soil structure. Eur. J. Soil Biol. 35, 153-161.

Hoffmann, T., Glatzel, S., Dikau, R., 2009. A carbon storage perspective on alluvial sediment storage in the Rhine catchment. Geomorphology 108, 127-137.

Kemper, W.D., Rosenau, R.C., 1986. Aggregate stability and size distribution. In: K.e. American Society of Agronomy - Soil Science Society of America (Ed.), Methods of Soil Analysis, Part 1. Agronomy Monograph No 9. ASA and SSSA, Madison, WI, pp. 425-442.

Lamas, F., Irigaray, C., Oteo, C., Chacon, J., 2005. Selection of the most appropriate method to determine the carbonate content for engineering purposes with particular regard to marls. Eng. Geol. 81, 32-41.

Mitra, S., Wassmann, R., Vlek, P.L.G., 2005. An appraisal of global wetland area and its organic carbon stock. Curr. Sci. 88 (1), 25-35.

Onweremadu, E.U., Izuogu, O.P., Akamigbo, F.O.R., 2010. Aggregation and pedogenesis of seasonally inundated soils of a tropical watershed. Chiang Mai J. Sci. 37 (1), 74-84.

Palmer, M.A., Bernhardt, E.S., 2006. Hydroecology and river restoration: ripe for research and synthesis. Water Resour. Res. 42 (3).

Palmer, M.A., Bernhardt, E.S., Allan, J.D., Lake, P.S., Alexander, G., Brooks, S., Carr, J. Clayton, S., Dahm, C.N., Shah, J.F., Galat, D.L., Loss, S.G., Goodwin, P., Hart, D.D., Hassett, B., Jenkinson, R., Kondolf, G.M., Lave, R., Meyer, J.L., O'Donnell, T.K., Pagano, L., Sudduth, E., 2005. Standards for ecologically successful river restoration. J. Appl. Ecol. 42, 208-217.

Pasquale, N., Perona, P., Schneider, P., Shrestha, J., Wombacher, A., Burlando, P., 2011. Modern comprehensive approach to monitor the morphodynamic evolution of a restored river corridor. Hydrol. Earth Syst. Sci. 15 (4), 1197-1212.

R Development Core Team, 2011. R: A Language and Environment for Statistical Computing. R Foundation for Statistical Computing, Vienna, Austria3-900051-07-0 (URL http://www.R-project.org/)

Samaritani, E., Shrestha, J., Fournier, B., Frossard, E., Gillet, F., Guenat, C., Niklaus, P.A., Pasquale, N., Tockner, K., Mitchell, E.A.D., Luster, J., 2011. Heterogeneity of soil carbon pools and fluxes in a channelized and a restored floodplain section (Thur River, Switzerland). Hydrol. Earth Syst. Sci. 15 (6), 1757-1769.

Schwartz, D., Namri, M., 2002. Mapping the total organic carbon in the soils of the Congo Glob. Planet. Chang. 33 (1-2), 77-93.

Six, J., Conant, R.T., Paul, E.A., Paustian, K., 2002. Stabilization mechanisms of soil organic matter: implications for C-saturation of soils. Plant Soil 241, $155-176$.

Steiger, J., Gurnell, A.M., Petts, G.E., 2001. Sediment deposition along the channel margins of a reach of the middle River Severn, UK. Regul. Rivers Res. Manag. 17 (4-5), $443-460$.

Tockner, K., Stanford, J.A., 2002. Riverine flood plains: present state and future trends. Environ. Conserv. 29, 308-330.

Unghire, J.M., Sutton-Grier, A.E., Flanagan, N.E., Richardson, C.J., 2011. Spatial impacts of stream and wetland restoration on riparian soil properties in the North Carolina Piedmont. Restor. Ecol. 19 (6), 738-746.

Van Cleve, K., Dyrness, C.T., Marion, G.M., Erickson, R., 1993. Control of soil development on the Tanana River floodplain, interior Alaska. Can. J. For. Res.-Rev. Can. Rech. For. 23 (5), 941-955. 
Viereck, L.A., Dyrness, C.T., Foote, M.J., 1993. An overview of the vegetation and soils of the floodplain ecosystems of the Tanana River, interior Alaska. Can. J. For. Res.-Rev. Can. Rech. For. 23 (5), 889-898.

von Lützow, M., Kögel-Knabner, I., Ekschmitt, K., Flessa, H., Guggenberger, G., Matzner, E. Marschner, B., 2007. SOM fractionation methods: relevance to functional pools and to stabilization mechanisms. Soil Biol. Biochem. 39, 2183-2207.
Wigginton, J.D., Lockaby, B.G., Trettin, C.C., 2000. Soil organic matter formation and sequestration across a forested floodplain chronosequence. Ecol. Eng. 15, 141-155.

Wohl, E., Dwire, K., Sutfin, N., Polvi, L., Bazan, R., 2012. Mechanisms of carbon storage in mountainous headwater rivers. Nat. Commun. 3, 1263-1270.

Zehetner, F., Lair, G.J., Gerzabek, M.H., 2009. Rapid carbon accretion and organic matter pool stabilization in riverine floodplain soils. Glob. Biogeochem. Cycles 23. 